\title{
Letter \\ Luminal B breast tumors are not HER2 positive
} Rohit Bhargava and David J Dabbs

Department of Pathology, Magee-Womens Hospital of University of Pittsburgh Medical Center, Halket Street, Pittsburgh, Pennsylvania 15213, USA

Corresponding author: Rohit Bhargava, rbhargava@mail.magee.edu

Published: 26 September 2008

Breast Cancer Research 2008, 10:404 (doi:10.1186/bcr2134)

This article is online at http://breast-cancer-research.com/content/10/5/404

(c) 2008 BioMed Central Ltd

See related research article by Tamimi et al., http://breast-cancer-research.com/content/10/4/R67

We read with interest the article by Tamimi and coworkers recently published in this journal [1]. The authors compared the molecular subtypes of invasive carcinoma versus ductal carcinoma in situ and found significant differences, as expected [1]. However, we have some concerns regarding the criteria used in the study.

First, the authors classified estrogen receptor (ER)-positive/ human epidermal growth factor receptor (HER)2-positive tumors as luminal B (LUMB). Although this classification is in accordance with that used in the Carolina Breast Cancer Study [2], the LUMB tumors - as identified by gene expression profiling - were all negative for HER2 [3]. The LUMB tumors are defined as tumors that show low to moderate expression of luminal specific genes, including the ER cluster $[3,4]$. Extrapolating these findings to routine practical use, one must use semiquantitative immunohistochemistry (Allred-score, Q-score, or an $\mathrm{H}$-score like method) [5-8] to define and distinguish luminal A (LUMA) and LUMB tumors. A large amount of information is lost when one labels a tumor as a mere ER-positive one, because a tumor in which $15 \%$ of cells exhibit weak ER staining is biologically different from one that demonstrates strong intensity staining in about $90 \%$ of cells. Although the vast majority of ER-positive tumors show strong immunoreactivity, approximately $20 \%$ of tumors exhibit variable ER expression. ER expression in breast carcinoma is a continuous variable, which has been demonstrated not only by immunohistochemistry and ligand binding assay, but also by quantitative RT-PCR assays [6,911]. Moreover, using data from the NSABP B-14 clinical trial, Baehner and coworkers [12] demonstrated that the greater benefit from tamoxifen is seen in patients with greater ER expression, as determined by RT-PCR.

Although it is difficult to define a cut-off, any ER-positive/ HER2-negative tumor showing diffuse and strong ER expression in two-thirds of the tumor (an H-score of 200 or higher) could be considered to be a LUMA tumor and the remainder of ER-positive/HER2-negative tumors could be considered LUMB. Although not the most accurate, this arbitrary cut-off is simple and keeps the category of LUMA tumors as pure as possible using immunohistochemistry. The ER-positive/HER2-positive tumors could similarly be subdivided into LUMA-HER2 hybrid (LAHH) and LUMBHER2 hybrid (LBHH), based on ER expression levels. The $\mathrm{LBHH}$ tumors probably correspond to the originally described luminal $\mathrm{C}$ tumors [3]. LAHH tumors definitely exist but do not have a molecular correlate. We believe that this distinction is necessary before studies utilizing surrogate immunohistochemical markers are undertaken, because HER2-positive tumors should be separated from pure luminal tumors, which should be further categorized as LUMA and LUMB tumors.

Second, the authors considered HER2 2+ expression by immunohistochemistry to be a positive finding. Numerous studies have shown that only one-quarter of immunohistochemical score 2+ cases demonstrate HER2 gene amplification by fluorescence in situ hybridization [13]. The authors did mention that 'the results of analyses in which HER2 positivity was defined as $3+$ were very similar to those presented with a definition of $2+$ and $3+$ '. However, the more important question is about the comparison of ' $2+$ only' cases with ' $3+$ only' cases.

\section{Competing interests}

The authors declare that they have no competing interests.

\section{References}

1. Tamimi RM, Baer HJ, Marotti J, Galan M, Galaburda L, Fu Y, Deitz AC, Connolly JL, Schnitt SJ, Colditz GA, Collins LC: Comparison of molecular phenotypes of ductal carcinoma in situ and invasive breast cancer. Breast Cancer Res 2008, 10:R67.

2. Carey LA, Perou CM, Livasy CA, Dressler LG, Cowan D, Conway K, Karaca G, Troester MA, Tse CK, Edmiston S, Deming SL, Geradts J, Cheang MC, Nielsen TO, Moorman PG, Earp HS, Millikan RC: Race, breast cancer subtypes, and survival in the Carolina Breast Cancer Study. JAMA 2006, 295:2492-2502.

3. Sørlie T, Perou CM, Tibshirani R, Aas T, Geisler S, Johnsen H, Hastie T, Eisen MB, van de Rijn M, Jeffrey SS, Thorsen T, Quist H, Matese JC, Brown PO, Botstein D, Eystein Lønning P, Børresen- 
Dale AL: Gene expression patterns of breast carcinomas distinguish tumor subclasses with clinical implications. Proc Natl Acad Sci USA 2001, 98:10869-10874.

4. Sorlie T: Molecular classification of breast tumors: toward improved diagnostics and treatments. Methods Mol Biol 2007, 360:91-114.

5. Goldstein NS, Ferkowicz M, Odish E, Mani A, Hastah F: Minimum formalin fixation time for consistent estrogen receptor immunohistochemical staining of invasive breast carcinoma. Am J Clin Pathol 2003, 120:86-92.

6. Harvey JM, Clark GM, Osborne CK, Allred DC: Estrogen receptor status by immunohistochemistry is superior to the ligandbinding assay for predicting response to adjuvant endocrine therapy in breast cancer. J Clin Oncol 1999, 17:1474-1481.

7. McCarty KS Jr, Miller LS, Cox EB, Konrath J, McCarty KS Sr: Estrogen receptor analyses. Correlation of biochemical and immunohistochemical methods using monoclonal antireceptor antibodies. Arch Pathol Lab Med 1985, 109:716-721.

8. Flanagan MB, Dabbs DJ, Brufsky AM, Beriwal S, Bhargava R: Histopathologic variables predict Oncotype DX ${ }^{\mathrm{TM}}$ Recurrence Score. Mod Pathol 2008 [Epub ahead of print].

9. Baehner FL, Maddala T, Alexander C, Gown A, Goldstein LC, Achacoso NS, Shak S, Quesenberry CP, Habel LA: A KaiserPermanente population-based study of ER and PR expression by the standard method, immunohistochemistry (IHC), compared to a new method, quantitative reverse transcription polymerase chain reaction (RT-PCR) [abstract 88]. In ASCO Breast Cancer Symposium 2007. [http://www.genomichealth.com/ pressroom/postersandabstracts.aspx?FileMateriallD $=38$ ]

10. Cronin M, Pho M, Dutta D, Stephans JC, Shak S, Kiefer MC, Esteban JM, Baker JB: Measurement of gene expression in archival paraffin-embedded tissues: development and performance of a 92-gene reverse transcriptase-polymerase chain reaction assay. Am J Pathol 2004, 164:35-42.

11. Lacroix M, Querton G, Hennebert P, Larsimont D, Leclercq G: Estrogen receptor analysis in primary breast tumors by ligand-binding assay, immunocytochemical assay, and northern blot: a comparison. Breast Cancer Res Treat 2001, 67:263271.

12. Baehner FL, Watson $D$, Shak $S$, Habel LA, Quesenberry CP, Capra A, Tang G, Paik S, Wolmark N: Quantitative RT-PCR analysis of ER and PR by Oncotype DX indicates distinct and different associations with prognosis and prediction of tamoxifen benefit [abstract 45]. In 29th Annual San Antonio Breast Cancer Symposium 2006. [http://www.genomichealth.com/ pressroom/postersandabstracts.aspx?FileMateriallD $=24]$

13. Lal P, Salazar PA, Hudis CA, Ladanyi M, Chen B: HER-2 testing in breast cancer using immunohistochemical analysis and fluorescence in situ hybridization: a single-institution experience of 2,279 cases and comparison of dual-color and single-color scoring. Am J Clin Pathol 2004, 121:631-636. 